\title{
Evaluation of Body Composition in Rural and Urban School children in a Municipality in the Southern Interior of the Legal Amazon
}

\section{Rafael Ayres Romanholo ${ }^{1}$, Laurindo Pereira de Souza ${ }^{2 *}$, Helizandra Simoneti Romanholo ${ }^{3}$, Marcia Guerino de Lima ${ }^{4}$ and Fabricio Moraes de Almeida ${ }^{5}$}

${ }^{1} \mathrm{PhD}$ in Regional Development and Environment-UNIR-Professor at the Federal Institute of Rondônia - IFRO Campos de Cacoal/RO - Researcher of the Human Motricity Research Group Health and Society (IFRO) Cacoal/Rondônia, Brazil ${ }^{2} P h D$ Student in Health Sciences at the Institute of Medical Assistance to Public Servants of the State of São Paulo-IAMSPE/SP, Master in Health Sciences by IAMSPE/SP, Coordinator of the Multiprofessional Residency Program in Intensive Care at Hospital Regional de Cacoal (HRC)/Rondônia, Brazil ${ }^{3}$ Master of Health Science - IAMSPE/SP Professor at the Cacoal University Center-UNIFACIMED, Rondônia, Brasil

${ }^{4}$ Obstetric Nurse, Specialist in Obstetrics and Social Obstetrics from the Faculdade da Alta Paulista-São Paulo. Professor at the Cacoal University Center-UNIFACIMED, Rondônia, Brasil

${ }^{5}$ Department of Electrical Engineering/PGDRA Master and Doctoral Program/ Leader of the Research Group - GEITEC (Management of Innovation and Technology), Brasil

*Corresponding Author: Laurindo Pereira de Souza, PhD Student in Health Sciences at the Institute of Medical Assistance to Public Servants of the State of São Paulo-IAMSPE/SP, Master in Health Sciences by IAMSPE/SP, Coordinator of the Multiprofessional Residency Program in Intensive Care at Hospital Regional de Cacoal (HRC)/Rondônia, Brazil.
Received: February 27, 2021

Published: March 11, 2021

(C) All rights are reserved by Laurindo

Pereira de Souza., et al.

\begin{abstract}
Objective: To evaluate the corporal composition in rural and urban schoolchildren in a city in the southern interior of the Western Amazon.

Method: This is a quantitative study classified as ex-post facto in order to verify the body composition of schoolchildren. The sample was composed of 482 students enrolled in rural and urban schools in the municipality of Cacoal-Rondônia (Brazil).

Results: Most of the students were female and lived in the rural area, the study revealed that the overweight indexes are high in both rural and urban schoolchildren, but with an increase for those who live in the city.

Conclusion: Obesity remains a serious public health problem in view of its rise for several years in this population profile, thus the involvement of the whole society is necessary, so that there is feasibility of health programs in schools in order to intensify actions aimed at nutritional support, physical activity, and the involvement of families to prevent and reduce the prevalence of this serious multifactorial disease.
\end{abstract}

Keywords: Obesity; Overweight; Body Mass Index; School Meals; Schoolchildren 


\section{Introduction}

Obesity is defined, according to the WHO [1] as "A disease in which excess body fat has accumulated to such an extent that health may be affected. This demonstrates the concern of this entity with the possible consequences of the accumulation of adipose tissue in the body.

Thus, obesity in school children has reached epidemic levels and is considered a chronic disease. Researchers are on the alert, because in recent decades obesity has been increasing in prevalence [2].

Yet in this context, another study [3] says that this disease is gaining much more space in the scientific field, in the media, and in the tabloids; however, it is also pointed out in the study that the tools and methods of research and evaluation are still proving ineffective for its "management".

In the 1990s, the gold standard for assessing body weight was weighing in water (submerged or hydrostatic weight). More recently, imaging techniques, such as magnetic resonance imaging, computed tomography, and dual-energy X-ray absorptiometry (dexa), have been alternatives; however, the cost and lack of the necessary equipment prevent the use of these techniques in clinical practice and especially by physical educators [4].

Assessments by skinfold measurement, ultrasonography, bioimpedance analysis, and infrared spectroscopy are available and relatively inexpensive. One can say that other ways to evaluate are through body mass index and abdominal circumference, which have been implemented in programs aimed at the population's health.

Studies and standardization of the Ministry of Health(Brazil) use the World Health Organization (WHO) table for classification of overweight and obesity, whose use has some limitations found in the literature. However, it presents a similar correlation with comorbidities. It is valid to state that the combination of Body Mass Index(BMI) with measurements of fat distribution can help to solve some problems of using BMI alone. Current studies indicate that waist circumference associated with BMI is used as the gold standard for determining obesity or overweight in children and adolescents [5].

A Ministry of Health(Brazil) survey reveals that, for the first time in eight consecutive years, the percentage of overweight and obesity has remained stable in the country. The Vigitel survey
(Surveillance of Risk and Protection Factors for Chronic Diseases by Telephone Inquiry), published in 2020, indicates that $20.3 \%$ of men and women are obese [6].

This same study highlighted that overweight was $55.4 \%$ for men, with a significant increase until 44 years of age; for women, this rate was $53.9 \%$ and may increase until 64 years of age, with extremes of education for both genders.

Faced with the above-mentioned problem, the present study aimed to evaluate the body composition in rural and urban schoolchildren in a city in the southern interior of the Western Amazon.

\section{Method}

This is a quantitative study classified as ex-post facto [7] with the purpose of verifying the body composition of schoolchildren. The study included 482 students, 371 enrolled in rural schools and 111 in urban schools, with ages ranging from 7 to 12 years old, residents of Cacoal, Rondônia (Brazil).

The sample size calculation was based on the statistical concepts of Kazmier (1982) [8], respecting a 0.05\% margin of error. After the application of the test we reached a percentage of $11.76 \%$ (totaling 482 students) of which 230 were males (178 rural and 52 urban) and 252 females (193 rural and 59 urban).

The sample selection criterion was carried out according to the method of drawing by school roll call, which were divided among 16 municipal schools, resulting in 63 students per school. To verify sample normality, the Kolmogorov-Smirnov test [9] was applied.

\section{Study protocol}

The study participants were weighed barefoot, wearing only their school uniform. To verify height, the students were placed standing with their heads positioned in the midline, knees extended, feet together, arms along the body, shoulders in contact with the wall, and in apnea. To collect BMI, a Filizola mechanical scale was used, with a $500 \mathrm{~g}$ and maximum of $220 \mathrm{~kg}$, coupled to a stadiometer with a $1 \mathrm{~cm}$ marker with a maximum height of $220 \mathrm{~cm}$, using the Quételet index: (underweight - BMI $<22 \mathrm{~kg} / \mathrm{m} 2$, eutrophic BMI between $22 \mathrm{~kg} / \mathrm{m} 2$ and $27 \mathrm{~kg} / \mathrm{m} 2$, and overweight - BMI > 27 $\mathrm{kg} / \mathrm{m} 2$ ) [10].

To verify the abdomen circumference, the assessed stood with relaxed abdomen, arms relaxed at the side of the body, the Sanny anthropometric tape measure without lock with 2 meters and millimeter scale, made of flat steel and ABS body, being flexible and inelastic, was placed without tissue compression horizontally at 
the midpoint between the lower edge of the last rib and the iliac crest [11].

In order to verify possible differences in the dependent variables between the study subgroups, Student's t-statistic for independent samples was used, to compare the mean of the groups a two-way analysis of variance (ANOVA) was applied, and finally, to detect possible differences in ages, the Scheffé "post-hoc" test was used. This test was used because the samples presented contrasting values in their ages, ranging from 7 to 12 years [12].

\section{Results}

It can be observed that, in general, for both places, the numbers of schoolchildren related to the male and female ages were not, percentually, very different. Analyzing both genders, we noticed the predominance of the analyzed schoolchildren who live in the rural area, due to the fact that the parents of the schoolchildren from the urban area adhered less to the research than the parents from the rural area, and also that more than $60 \%$ of the schools examined were from the rural area (Table 1 ).

\begin{tabular}{|c|c|c|c|c|c|c|c|}
\hline \multirow{2}{*}{\begin{tabular}{|l} 
Sex \\
Male
\end{tabular}} & \multirow{2}{*}{$\begin{array}{c}\text { Age } \\
7 \\
\end{array}$} & \multicolumn{2}{|c|}{ Urban Zone } & \multicolumn{2}{|c|}{ Rural Zone } & \multicolumn{2}{|c|}{ Both } \\
\hline & & 9 & $17 \%$ & 21 & $12 \%$ & 30 & $13 \%$ \\
\hline & 8 & 5 & $10 \%$ & 24 & $13 \%$ & 29 & $13 \%$ \\
\hline & 9 & 18 & $35 \%$ & 17 & $10 \%$ & 35 & $15 \%$ \\
\hline & 10 & 15 & $29 \%$ & 41 & $23 \%$ & 56 & $24 \%$ \\
\hline & 11 & 4 & $8 \%$ & 34 & $19 \%$ & 38 & $17 \%$ \\
\hline & 12 & 1 & $2 \%$ & 41 & $23 \%$ & 42 & $18 \%$ \\
\hline Mean & 9,7 & & & & & & \\
\hline sd & 1,3 & & & & & & \\
\hline \multicolumn{2}{|l|}{ Total } & 52 & $100 \%$ & 178 & $100 \%$ & 230 & $100 \%$ \\
\hline \multirow[t]{6}{*}{ Female } & 7 & 15 & $25 \%$ & 32 & $17 \%$ & 47 & $19 \%$ \\
\hline & 8 & 11 & $19 \%$ & 24 & $12 \%$ & 35 & $14 \%$ \\
\hline & 9 & 13 & $22 \%$ & 25 & $13 \%$ & 38 & $15 \%$ \\
\hline & 10 & 18 & $31 \%$ & 27 & $14 \%$ & 45 & $18 \%$ \\
\hline & 11 & 2 & $3 \%$ & 36 & $19 \%$ & 38 & $15 \%$ \\
\hline & 12 & 0 & $0 \%$ & 49 & $25 \%$ & 49 & $19 \%$ \\
\hline Mean & 9,5 & & & & & & \\
\hline sd & 1,4 & & & & & & \\
\hline \multicolumn{2}{|l|}{ Total } & 59 & $100 \%$ & 193 & $100 \%$ & 252 & $100 \%$ \\
\hline
\end{tabular}

Table 1: Distribution of students according to sex and location - urban and rural zone.

Source: The authors themselves. Legends: Standard Deviation: sd.
Aiming to investigate statistically significant differences at p0.05 level among the sample subjects, table 2 shows the comparative analysis between the study subgroups, which are classified as: a) RSSG for the sample composed of regular rural school students; and b) USSG for the sample formed by students regularly enrolled in urban schools. In view of the analysis, table 2 revealed that for independent samples there were no significant differences between the means of the variables, demonstrating the homogeneity between the groups.

\begin{tabular}{|l|c|c|c|c|}
\hline \multirow{2}{*}{ Variables } & \multicolumn{4}{|c|}{ Male study groups } \\
\cline { 2 - 4 } & \multicolumn{2}{|c|}{ Subgroups } & \multirow{2}{*}{ t* $^{*}$ p } \\
\hline AGE (years) & $9,8+-1,23$ & $9,6+-1,13$ & 1,688 & 0,675 \\
\hline TBW (kg) & $36,4+-3,6$ & $32,7+-2,4$ & 1,233 & 0,541 \\
\hline S (cm) & $140+-12$ & $135+-10$ & 1,567 & 0,521 \\
\hline Variables & \multicolumn{3}{|c|}{ Female study groups } \\
\cline { 2 - 3 } & \multicolumn{2}{|c|}{ Subgroups } & t* & p \\
\hline \multirow{2}{*}{ AGE (years) } & $9,84+-1,4$ & $9,1+-0,56$ & 1,432 & 0,521 \\
\hline TBW (kg) & $35,85+-3,51$ & $31,32+-2,34$ & 1,121 & 0,512 \\
\hline S (cm) & $141+-11$ & $139+-10$ & 1,111 & 0,551 \\
\hline
\end{tabular}

Table 2: Physical characteristics of the sample divided by location. Source: The authors themselves.

Legends: *t Student; Total Body Weight(TBW); Stature(S).

Tables 3 and 4 present the prevalence of obesity by classifying the BMI as normal, overweight and obesity, and the waist circumference as: no risk, risk limit and above the risk limit, in the alteration in schoolchildren from 7 to 12 years old, separated by age, gender and location (rural or urban zone).

When evaluating the BMI of students from the urban area, it was observed that the frequency of normality, overweight and obesity were $69 \%, 19 \%$ and $12 \%$, respectively, in males, and $77 \%$, $10 \%$ and $13 \%$ in females. When evaluating the BMI of the schoolchildren in the rural area, the BMI of normal, overweight and obese was $76.8 \%, 14.5 \%$ and $8.7 \%$ for males, and normal $81 \%, 14 \%$ overweight and $5 \%$ obese for females. In the abdominal circumference variable, $53.9 \%$ of the urban male students were classified as not being at risk, $40.4 \%$ as being at risk limit and $5.7 \%$ as being 
above the limit, and the female students in the same place were $57.6 \%$ not being at risk, $32.2 \%$ as being at risk limit and $10.2 \%$ as being above the risk limit. In the rural zone, the male sex presented as without risk $65.9 \%$, with the risk limit of $29.6 \%$ and $4.6 \%$ above the risk limit, and the female sex $68.2 \%$ classified as without risk, $26.3 \%$ risk limit of $5.5 \%$ as above the risk limit.

As for the abdominal circumference variable, $53.9 \%$ of the male students in the urban area were classified as having no risk, with a risk limit of $40.4 \%$ and above the limit of $5.7 \%$; those females in the same location had $57.6 \%$ without risk, $32.2 \%$ at the risk limit and $10.2 \%$ above the risk limit. With a total of 371 students in the rural area, males were $65.9 \%$ without risk, $29.6 \%$ at the risk limit and $4.6 \%$ above the risk limit; females were $68.2 \%$ classified as without risk, $26.3 \%$ at the risk limit and $5.5 \%$ as above the risk limit.

\begin{tabular}{|c|c|c|c|c|c|c|c|}
\hline \multirow[t]{2}{*}{ Sex } & \multirow[t]{2}{*}{ Age } & \multicolumn{3}{|c|}{ BMI } & \multicolumn{3}{|c|}{$\begin{array}{c}\text { Abdominal } \\
\text { Circumference }\end{array}$} \\
\hline & & Normal & $\begin{array}{c}\text { Over } \\
\text { weight }\end{array}$ & Obese & No risk & Limit & $\begin{array}{c}\text { Above } \\
\text { the } \\
\text { Limit }\end{array}$ \\
\hline \multirow[t]{6}{*}{ Male } & 7 & 18 & 1 & 3 & 11 & 8 & 3 \\
\hline & 8 & 15 & 8 & 0 & 16 & 7 & 0 \\
\hline & 9 & 16 & 0 & 1 & 10 & 7 & 0 \\
\hline & 10 & 31 & 3 & 5 & 28 & 10 & 1 \\
\hline & 11 & 25 & 4 & 2 & 25 & 4 & 2 \\
\hline & 12 & 28 & 9 & 4 & 24 & 15 & 2 \\
\hline Total & & $133(76,8 \%)$ & $\begin{array}{c}25 \\
(14,5 \%)\end{array}$ & $\begin{array}{c}15 \\
(8,7 \%)\end{array}$ & $\begin{array}{c}114 \\
(65,9 \%)\end{array}$ & $5129,6 \%)$ & $8(4,6 \%)$ \\
\hline \multirow[t]{6}{*}{ Female } & 7 & 23 & 5 & 3 & 16 & 13 & 2 \\
\hline & 8 & 18 & 2 & 4 & 15 & 5 & 4 \\
\hline & 9 & 21 & 4 & 2 & 19 & 7 & 1 \\
\hline & 10 & 22 & 5 & 1 & 22 & 4 & 2 \\
\hline & 11 & 36 & 2 & 0 & 32 & 6 & 0 \\
\hline & 12 & 42 & 7 & 1 & 31 & 17 & 2 \\
\hline Total & & 162 (81\%) & $25(14 \%)$ & $\begin{array}{c}11 \\
(5 \%)\end{array}$ & $\begin{array}{c}135 \\
(68,2 \%)\end{array}$ & $52(26,3 \%)$ & $\begin{array}{c}11 \\
(5,5 \%)\end{array}$ \\
\hline
\end{tabular}

Table 3: Characterization of the sample by rural zone.

Source: The authors themselves.

Legends: Abdominal Circumference(AC); Body Mass Index(BMI).

Table 5 shows the comparison between the schools and genders in the BMI and AC variables. When the genders were compared to the school's location, it was verified that there was no significant difference.

\begin{tabular}{|c|c|c|c|c|c|c|c|}
\hline \multirow[t]{2}{*}{ Sex } & \multirow[t]{2}{*}{ Age } & \multicolumn{3}{|c|}{ BMI } & \multicolumn{3}{|c|}{$\begin{array}{c}\text { Abdominal } \\
\text { Circumference }\end{array}$} \\
\hline & & Normal & $\begin{array}{c}\text { Over } \\
\text { weight }\end{array}$ & Obese & No risk & Limit & $\begin{array}{c}\text { Above } \\
\text { the } \\
\text { Limit }\end{array}$ \\
\hline \multirow[t]{6}{*}{ Male } & 7 & 7 & 2 & 0 & 3 & 6 & 0 \\
\hline & 8 & 2 & 3 & 0 & 3 & 2 & 0 \\
\hline & 9 & 11 & 2 & 5 & 10 & 6 & 2 \\
\hline & 10 & 12 & 2 & 1 & 8 & 6 & 1 \\
\hline & 11 & 3 & 1 & 0 & 3 & 1 & 0 \\
\hline & 12 & 1 & 0 & 0 & 1 & 0 & 0 \\
\hline Total & & $\begin{array}{c}36 \\
(69 \%)\end{array}$ & $\begin{array}{c}10 \\
(19 \%)\end{array}$ & $\begin{array}{c}6 \\
(12 \%)\end{array}$ & $\begin{array}{c}28 \\
(53,9 \%)\end{array}$ & $\begin{array}{c}21 \\
(40,4 \%)\end{array}$ & $\begin{array}{c}3 \\
(5,7 \%)\end{array}$ \\
\hline \multirow[t]{6}{*}{ Female } & 7 & 14 & 1 & 2 & 7 & 8 & 2 \\
\hline & 8 & 11 & 0 & 0 & 8 & 2 & 1 \\
\hline & 9 & 7 & 2 & 2 & 6 & 5 & 0 \\
\hline & 10 & 13 & 2 & 3 & 12 & 3 & 3 \\
\hline & 11 & 1 & 1 & 0 & 1 & 1 & 0 \\
\hline & 12 & 0 & 0 & 0 & 0 & 0 & 0 \\
\hline Total & & $\begin{array}{c}46 \\
(77 \%)\end{array}$ & $6(10 \%)$ & $\begin{array}{c}7 \\
(13 \%)\end{array}$ & $\begin{array}{c}34 \\
(57,6 \%)\end{array}$ & $\left(\begin{array}{c}19 \\
(32,2 \%)\end{array}\right.$ & $\begin{array}{c}6 \\
(10,2 \%)\end{array}$ \\
\hline
\end{tabular}

Table 4: Characterization of the sample per location urban zone. Source: The authors themselves.

Legends: Abdominal Circumference(AC); Body Mass Index(BMI).

\begin{tabular}{|l|c|c|}
\hline \multicolumn{3}{|c|}{ Comparison of variables by gender urban zone } \\
\hline Variables & $\mathbf{t}^{*}$ & $\mathbf{p}$ \\
\hline BMI & 1.113 & 0,689 \\
\hline AC & 1.946 & 0,767 \\
\hline CR & -146 & 0,6472 \\
\hline Comparison of variables by gender rural zone \\
\hline Variables & \multicolumn{1}{|c|}{$\mathbf{t}^{*}$} & $\mathbf{p}$ \\
\hline BMI & 1.239 & 0,772 \\
\hline AC & 1.387 & 0,657 \\
\hline CR & -1.371 & 0,612 \\
\hline
\end{tabular}

Table 5: independent t test of BMI, AC and CR variables comparing the gender of urban and rural school kids. Source: The authors themselves.

Legend: abdominal circumference(AC); cardiac risk(RC); body mass index(BMI) and *t Student. 


\section{Discussion}

In view of the results presented, the research makes it evident that the population of obese and overweight people has been growing in recent years. In the study, some data called attention to the direction that obesity and overweight have been taking in the studied population.

It was possible to observe that the overweight indexes are high in the rural and urban schoolchildren, with an increase for those who live in the city. In general, it was observed that for both locations, the difference between the ages of the school children did not have significant differences. The study showed that there was a predominance in both genders of the rural area residents, a fact justified, due to the fact that those who live in this locality were more than $60 \%$ examined, while the others live in the city and were a smaller sample of parents who agreed to participate in the study.

Through the studies, it was possible to notice that, in the last few years, obesity in schoolchildren has been increasing significantly. For these researchers [13-15], the estimate was $20 \%$ of obese schoolchildren. In another study ${ }^{16}$ conducted by the WHO, we could notice an increase of $5 \%$ to $8 \%$ in this percentage, that is, it was possible to verify that we have almost $30 \%$ of obese or overweight schoolchildren.

In addition, some studies $[4,5,17,18]$ point out that obesity can be influenced by environmental, psychological, and social factors. However, the data and studies pointing to these factors are scarce, because they only point to suppositions, and not to cause-effect studies, really showing the triggering factors of this disease.

Another limiting factor in some studies is that they have taken into account only BMI as the cut-off point for diagnosing obesity. This indicator is important to assess obesity, but it is very reductionist to use this tool only as an evaluator of this disease. We should use other ways to associate it, for example, abdominal circumference.

They also reinforce [17] in their study, conducted in the interior of the state of Paraná, that $10 \%$ of the children had obesity centered in the abdomen.

In another research carried out in the countryside of São Paulo state, the authors verified a strong association between obesity and abdominal circumference, besides a significant increase in blood pressure in schoolchildren [18].
And finally, the studies $[4,19]$ conducted by experts who have been studying obesity for several years in schoolchildren in the city of Cacoal, in the state of Rondônia(Brazil), verified positive and significant relationships between obesity and motor coordination, obesity and stress, and obesity and self-image. With this, it is interesting to verify that obesity is a disease that involves not only the appearance of the human being, but in other structures and body systems.

For Romanholo., et al. (2012) [19], obesity has increased alarmingly in developed and developing countries. In the 1990s, one in five American adolescents was overweight (1988-1991), showing a $40 \%$ increase in prevalence for this age group [20].

Results of the Mônica study (Monitoring of Trends and Determinants in Cardiovascular Diseases 1993-1996) showed an increase in the prevalence of obesity of between $10 \%$ and $40 \%$ in most European countries, with the largest increase in England, where the prevalence doubled, and is always associated with poor diet and an increase in sedentary lifestyles [15].

Past studies have provided information on obesity in adolescents ranging from $8 \%$ to $20 \%$ in different geographical locations. Data on the prevalence of overweight and obesity in adolescence were scarce; today, we can cite some classic studies $[4,13,18,21,22]$.

Obesity is associated with important metabolic alterations, which are dependent on their duration and severity, the consequences of which occur more in adults. However, the obese child already presents a higher risk for developing some diseases and psychosocial disorders caused by the stigma of obesity, which are of great relevance in this phase of personality structuring [23,24].

Two studies [25] were important in the prevention and treatment of obesity. The first study was published by the WHO in 1998, which proposed a classification for body weight based on body mass index (BMI); with the support of most countries, this WHO goal was successfully achieved. The second study by the same author was published in late 1998 by the National Institutes of Hearth (NIH). The goal of the study was to offer some guidelines for the prevention and treatment of obesity and its chronic diseases or comorbidities. Compared to the current study, it can be seen that the worldwide data on obesity and cardiac risk have been growing exponentially.

One can compare, with the current study, the analysis of abdominal obesity in children and adolescents developed in the city of Cascavel, Paraná, Brazil, an analysis that performed several as- 
sessments, including BMI and waist circumference. In this study, the prevalence of abdominal obesity is close to $10 \%$ and the factors associated with the outcome were school grade and nutritional status. Educational actions should be emphasized among schools, with special attention to those in elementary school and with students who present excess body weight [17].

The notes have warned about the increase in obesity in children, pointing to the possibility of obese children becoming obese adults.

\section{Conclusion}

Before the objective of the study, which was to evaluate the corporal composition in schoolchildren who live in urban and rural zone, it was concluded that the prevalence of obesity and overweight has been increasing in schoolchildren, especially in those who live in the city.

Furthermore, the research reaffirmed information already revealed in other studies led by the WHO that the higher the risk of obesity and overweight, the higher the chance of these younger students to become obese adults and develop metabolic risk and cardiovascular diseases. These results point to the emerging need that strategies to control these diseases should be planned and implemented, emphasizing the importance of a careful approach to children in the school environment, especially those with similar characteristics and with potential risk of obesity and overweight.

Considering obesity as a global public health problem, it is imperative that schools adopt rigorous nutritional monitoring early on, in addition to health education through health programs in schools aimed at promoting healthy eating, encouraging physical activity and family involvement in this school period.

\section{Bibliography}

1. World Health Organization. WHO. Report of a WHO Consultation on Obesity. Preventing and managing the global epidemic. WHO, Geneve (2000).

2. Andrade J., et al. "Intervenções escolares para redução da obesidade infantil: uma revisão sistemática”. Ciência and Saúde 8.2 (2015): 72-78.

3. Williams JD., et al. "Introduction: Childhood Obesity: media, advertising, community, and advocacy". In: Advances in Communication Research to Reduce Childhood Obesity. Springer, New York, NY, (2013): 3-18.
4. Romanholo RA., et al. "Análise da imagem corporal em escolares de 7 a 12 anos dos gêneros masculino e feminino do município de Cacoal/RO”. RBPFEX - Revista Brasileira De Prescrição E Fisiologia Do Exercício 8.50 (2014).

5. Halpern R., et al. "Correlação entre variáveis antropométricas em escolares na cidade de Caxias do Sul". Do Corpo: ciências e artes 1.3 (2014).

6. Brasil. Ministério da Saúde. Vigilância de Fatores de Risco e Proteção para Doenças Crônicas por Inquérito Telefônico, VIGITEL. Estimativas sobre frequência e distribuição sócio demográfica de fatores de risco e proteção para doenças crônicas nas capitais dos 26 estados brasileiros e no distrito federal em 2019. Brasília-DF: Ministério da Saúde (2020).

7. Gil AC. "Como elaborar projetos de pesquisa". 4. ed. São Paulo: Atlas (2007).

8. Kazmier LJ. "Estatística aplicada à economia e administração". McGraw-Hill (1982).

9. Padovani CR. Bioestatística. São Paulo: Cultura Acadêmica: Universidade Estadual Paulista, Pró-Reitoria de Graduação (2012).

10. Cervi A., et al. "Análise crítica do uso do índice de massa corporal para idosos Critical analysis of the use of the body mass index for the elderly". Revista de nutrição 18.6 (2005): 765-775.

11. Soar C., et al. "Relação cintura quadril e o perímetro da cintura associados ao índice de massa corporal em estudo com escolares Cad". Saúde Pública 20.6 (2004): 1609-1616.

12. Bussab WO and Morettin PA. "Estatística básica". Saraiva (2010).

13. Romanholo RA., et al. "Índice de pressão arterial e obesidade em escolares de etnias brancas e negras de 7 a 12 anos dos ensinos públicos e privados do município de Cacoal - RO”. 2011. RBPFEX - Revista Brasileira De Prescrição E Fisiologia Do Exercício 2.10 (2011).

14. World Health Organization. WHO. Obesity: preventing and managing the global epidemic. Report of a World Health Organization Consultation. Geneva: World Health Organization (2000) 256.

15. World Health Organization. WHO. National cancer control programmes. Policies and managerial guidelines, 2nd edn. Geneva: WHO (2010.) 
16. World Health Organization. WHO. "7 million premature deaths annually linked to air pollution" (2014).

17. Herrmann CS., et al. "Transcranial alternating current stimulation: a review of the underlying mechanisms and modulation of cognitive processes". Frontiers in Human Neuroscience 7 (2013).

18. Del Vecchio F., et al. "Sistema Único de Saúde e Educação Física: Aproximações a partir do grupo de epidemiologia da atividade física-atenção básica" (2014).

19. Romanholo RA., et al. "Análise da relação entre a maturação biológica e estresse na coordenação motora grossa em escolares de 5 a 10 anos". Revista Brasileira de Ciência e Movimento 20.2 (2012): 91-97.

20. Gatti BA. "Pesquisa, educação e pós-modernidade: confrontos e dilemas". Cadernos de pesquisa 35.126 (2005): 595-608.

21. Malta D., et al. "Política Nacional de Promoção da Saúde, descrição da implementação do eixo atividade física e práticas corporais, 2006 a 2014". Revista Brasileira de Atividade Física and Saúde 19.3 (2014): 286.

22. Silva VM., et al. "Impacto do uso de estratégias investigativas sobre as emoções e a motivação dos alunos e as suas concepções de ciência e cientista”. Revista Electrónica de Enseñanza de las Ciencias 14.1 (2015): 17-34.

23. Victorino SVZ., et al. "Viver com obesidade infantil: a experiência de crianças inscritas em programa de acompanhamento multidisciplinary". Northeast Network Nursing Journal 15.6 (2015).

24. Escrivão MAMS., et al. "Obesidade exógena na infância e na adolescência”. Journal of Pediatric 76 (2000): S305-S310.

25. Bouchard G., et al. "Fathers' motivation for involvement with their children: A self-determination theory perspective". Fathering: A Journal of Theory, Research, and Practice about Men as Fathers 5.1 (2007): 25-41.

\section{Assets from publication with us}

- Prompt Acknowledgement after receiving the article

- Thorough Double blinded peer review

- Rapid Publication

- Issue of Publication Certificate

- High visibility of your Published work

Website: www.actascientific.com/

Submit Article: www.actascientific.com/submission.php

Email us: editor@actascientific.com

Contact us: +919182824667 